\title{
THE REMOVAL OF THE SEMINAL VESICLES FROM THE BOAR AND THE EFFECTS ON THE SEMEN CHARACTERISTICS
}

\author{
D. C. DAVIES, G. HALL, K. G. HIBBITT and H. D. M. MOORE \\ Agricultural Research Council Institute for Research on Animal Diseases, \\ Compton, Newbury, Berkshire
}

(Received 16th October 1974)

\begin{abstract}
Summary. A technique is described for the removal of the seminal vesicles from the boar. The operation was carried out on twelve animals and six of the animals were subsequently trained for semen collection. The seminal plasma from the boars after surgery compared with normal litter mates had a more watery consistency and did not form the characteristic gel during ejaculation. The sperm concentration was $49 \%$ lower while the total reduction of sperm number/ejaculate was $78 \%$ in the experimental animals, but the ratio of living to dead spermatozoa remained unchanged. The concentrations of citrate and protein were significantly depressed in the seminal plasma of the animals after surgery and the $\mathrm{pH}$ increased; the osmolarity remained unchanged. Insemination of gilts with the semen from experimental boars revealed no significant loss of fertility compared with the normal controls. Animals slaughtered up to 17 months after surgery showed no regeneration of the seminal vesicles.
\end{abstract}

\section{INTRODUCTION}

The majority of the protein components in the seminal plasma of the boar are secreted by the seminal vesicles (Boursnell, Johnson \& Zamora, 1962). Three principal components are involved, two of which, $\mathrm{A}$ and $\mathrm{H}$, are positively charged and have isoelectric points of 8.8 and $9 \cdot 4$, respectively (Boursnell \& Briggs, 1969). Reports from the literature indicate that basic proteins can increase the permeability of biological membranes (Ryser \& Hancock, 1965; Drew \& McLaren, 1970; Hibbitt \& Benians, 1971), so it is conceivable that components $\mathrm{A}$ and $\mathrm{H}$ may have a similar activity on the plasma and acrosomal membranes of boar spermatozoa, thereby rendering them particularly susceptible to damage during the process of freezing.

The effects of the seminal plasma basic proteins on boar spermatozoa can only be measured in controlled experiments comparing semen from normal boars with those in which seminal vesicle glands have been surgically removed. Removal of the seminal vesicles has been described in the bull (Hess, Ludwick, Martrig \& Ely, 1960; King \& MacPherson, 1968; Shah, Hopwood \& Faulkner, 
1968), but there appears to be little information on the removal of these accessory glands from the boar. Even though McKenzie, Miller \& Bauguess (1938) and Schellpfeffer \& Hunter (1970) carried out experiments on boars after the removal of the seminal vesicles, the surgical techniques were not described.

The objective of this study was to develop and describe a technique for the removal of the seminal vesicles from boars. The progress of these animals was then followed for 2 years, and the effects of the surgical interference on the quality of the semen was studied.

\section{MATERIALS AND METHODS}

Animals

Large White boars which had a good breeding potential were selected from the Institute's minimal disease herd. In the first series of experiments, surgery was performed at 4 to 8 months; in the later studies, however, the surgical technique was applied to the adult animal.

\section{Premedication and anaesthesia}

The animals were fasted for $24 \mathrm{hr}$ before the operation. They were premedicated 15 to $20 \mathrm{~min}$ before the induction of anaesthesia by injecting intramuscularly a $4 \%$ solution of Azaperone (Suicalm, Crown Chemical Company Ltd, Lamberhurst, Kent) at a dosage rate of $2 \mathrm{ml} / 20 \mathrm{~kg}$ body weight. Anaesthesia was induced by halothane administered through an open mask from a Boyle apparatus. When surgical anaesthesia supervened, a MacGill cuffed endotracheal tube of suitable size was passed and connected to a 'to-and-fro' absorption system. Anaesthesia was maintained with a halothane-oxygen mixture.

\section{Surgical technique}

A 15-cm abdominal incision was made close to and parallel with the prepuce, extending forward from the pelvic brim. The procedure on entering the abdominal cavity was to identify the urinary bladder. It was brought out through the wound to the surface and reflected backwards, thereby allowing the seminal vesicles to be grasped. The seminal vesicles of the boar are two large pyramidal shaped masses of glandular tissue which lie (Text-fig. 1; P1. 1, Fig. 1) dorsal to, and cover the neck of, the bladder, the ureters, the ductus deferentes and the prostate gland. The glands lie in close proximity to the urethra and the anterior regions of the bulbourethral glands. The tissue has a pale pink colour, is distinctly lobate and is covered with a thin fibrous capsule. The connective tissue between the seminal vesicle capsules and the surrounding structures was gently broken down by blunt dissection until the prostate gland was identified adjacent to the colliculus seminalis (Text-fig. 1 and P1. 1, Fig. 1). Careful blunt dissection was used to minimize the risk of rupturing the seminal vesicle capsule, which would lead to the release of copious volumes of vesicular fluid. Extreme care was also necessary to avoid damage to the ductus deferentes and the ureters at the point where they curve around the seminal vesicles before entering the urethra and bladder, respectively. After 
careful dissection from the surrounding tissues (Pl. 1, Fig. 2), the seminal vesicles were finally removed by a twisting movement. Haemorrhage was rarely a problem and seepage was controlled by swabbing; any severe haemorrhage was controlled by diathermy, haemostatic forceps or ligation.

After removal of the seminal vesicles, the bladder was restored to its normal position and a soluble antibiotic preparation (Terramycin soluble powder: Pfizer, Sandwich, Kent) was placed in the abdominal cavity before closing the laparotomy incision using normal surgical techniques.

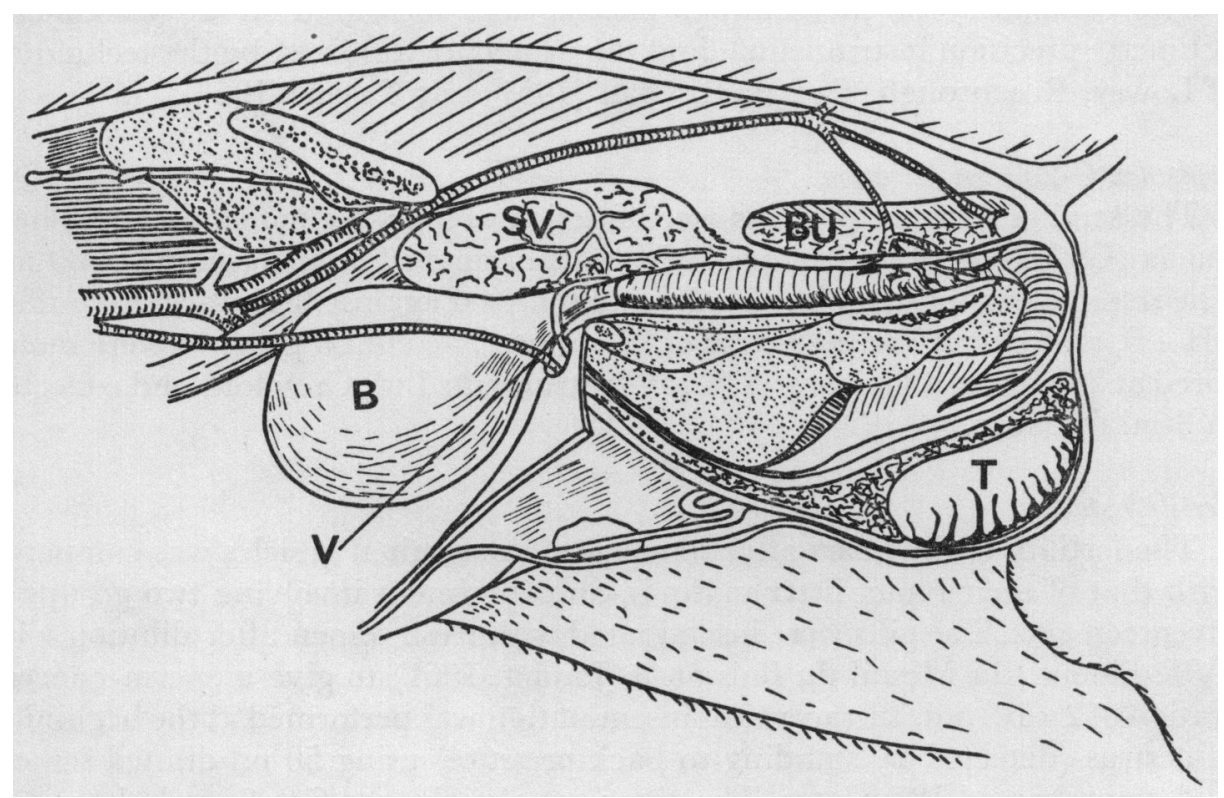

TEXT-FIG. 1. Sagittal section of the pelvic region of the boar. B, bladder; BU, bulbourethral gland; SV, seminal vesicles; $\mathrm{T}$, testis; $\mathrm{V}$, ductus deferens.

\section{Postoperative treatment}

Immediately after surgery, $250 \mathrm{mg}$ hydrochlorothiazide (Vetidrex: Ciba, Cambridge) diuretic was injected intramuscularly to reduce tissue oedema and an injection was given of 3 mega units of a long-acting penicillin preparation (Penidural: John Wyeth and Brother, Maidenhead, Berks). The animals were subsequently trained for semen collection when they were approximately 1 year old.

\section{Semen collection}

Semen was collected by the gloved hand technique (Hancock \& Hovell, 1959) through gauze into a prewarmed vacuum flask at $30^{\circ} \mathrm{G}$. Samples were collected from three experimental and two intact boars. The intact and experimental animals were litter mates and therefore of similar age and genetic background.

\section{Semen analysis}

Immediately after collection, the whole ejaculate was divided into two portions and a sample of seminal plasma was prepared by centrifuging the semen 
at $10,000 \mathrm{~g}$ for $30 \mathrm{~min}$ at $25^{\circ} \mathrm{C}$; the supernatant seminal plasma was stored at $-20^{\circ} \mathrm{G}$. The sperm concentration (Neubauer double haemocytometer), live: dead sperm ratio (Dott \& Foster, 1972), $\mathrm{pH}$ (Pye Unicam Instruments, Cambridge) and citrate concentration (Mollering \& Gruber, 1966) were determined on the rest of the fresh ejaculate. For the citrate determinations, the semen was deproteinized by adding $1.0 \mathrm{ml}$ semen to $10.0 \mathrm{ml}$ ice-cold $0.6 \mathrm{M}$-perchloric acid. The precipitated protein and spermatozoa were removed by centrifugation and the supernatant was neutralized with $20 \% \mathrm{KOH}$.

The osmolarity of the seminal plasma was measured in an osmometer (Osmette precision instruments), and the protein determined by the techniques of Lowry, Rosebrough, Farr \& Randall (1951) and Layne (1957).

\section{Sephadex G-200 gel filtration}

The seminal plasma proteins were fractionated on Sephadex G-200 (Pharmacia (Gt Britain) London) packed in a column with a bed volume of $80 \mathrm{ml}$. The seminal plasma samples $(2 \mathrm{ml})$ were dialysed against $0.1 \mathrm{M}$-acetate buffer, $\mathrm{pH} 4 \cdot 0$, and eluted at a flow rate of $21 \mathrm{ml} / \mathrm{hr}$. The eluted proteins were monitored at $280 \mathrm{~nm}$ in a Uvicord II (LKB Instruments Ltd, Croydon) and collected in 3-ml fractions.

\section{Fertility studies}

The fertility of the boars after removal of the seminal vesicles was compared with that of their intact litter mates in an experiment involving two groups of seventeen gilts. The gilts were inseminated with fresh semen after dilution with IVT diluent (du Mesnil du Buisson \& Jondet, 1961) to give a sperm concentration of $2 \times 10^{7} / \mathrm{ml}$. Intracervical insemination was performed at the beginning of oestrus (detected by standing to back pressure) using $50 \mathrm{ml}$ diluted semen, and was repeated $18 \mathrm{hr}$ later. The gilts were slaughtered 6 to 8 weeks later and their reproductive tracts were examined.

\section{Seminal vesiculectomy}

\section{RESULTS}

The surgical removal of the seminal vesicles was studied in animals of various ages. The development of these glands depends on the presence of circulating androgens and, in a preliminary study, no glandular tissue was found before 8 weeks of age. In the fully mature boar, the glands weighed up to $240 \mathrm{~g}$ each.

Surgery was first carried out on boars between 4 and 8 months of age; as the surgical technique was developed, however, it was shown that the procedure could be applied equally well to adult animals.

The results of surgery on the twelve animals in this study (nine between 4 and 6 months and three between 9 and 12 months) are shown in Table 1.

\section{EXPLANATION OF PLATE 1}

Fig. 1. Seminal vesicles dissected from the surrounding tissues and ready for removal. The ureters and ductus deferentes are not visible. B, bladder; SV, seminal vesicles.

FIg. 2. Seminal vesicle glands removed with intact capsules. B, bladder; SV, seminal vesicles. 
PLATE 1

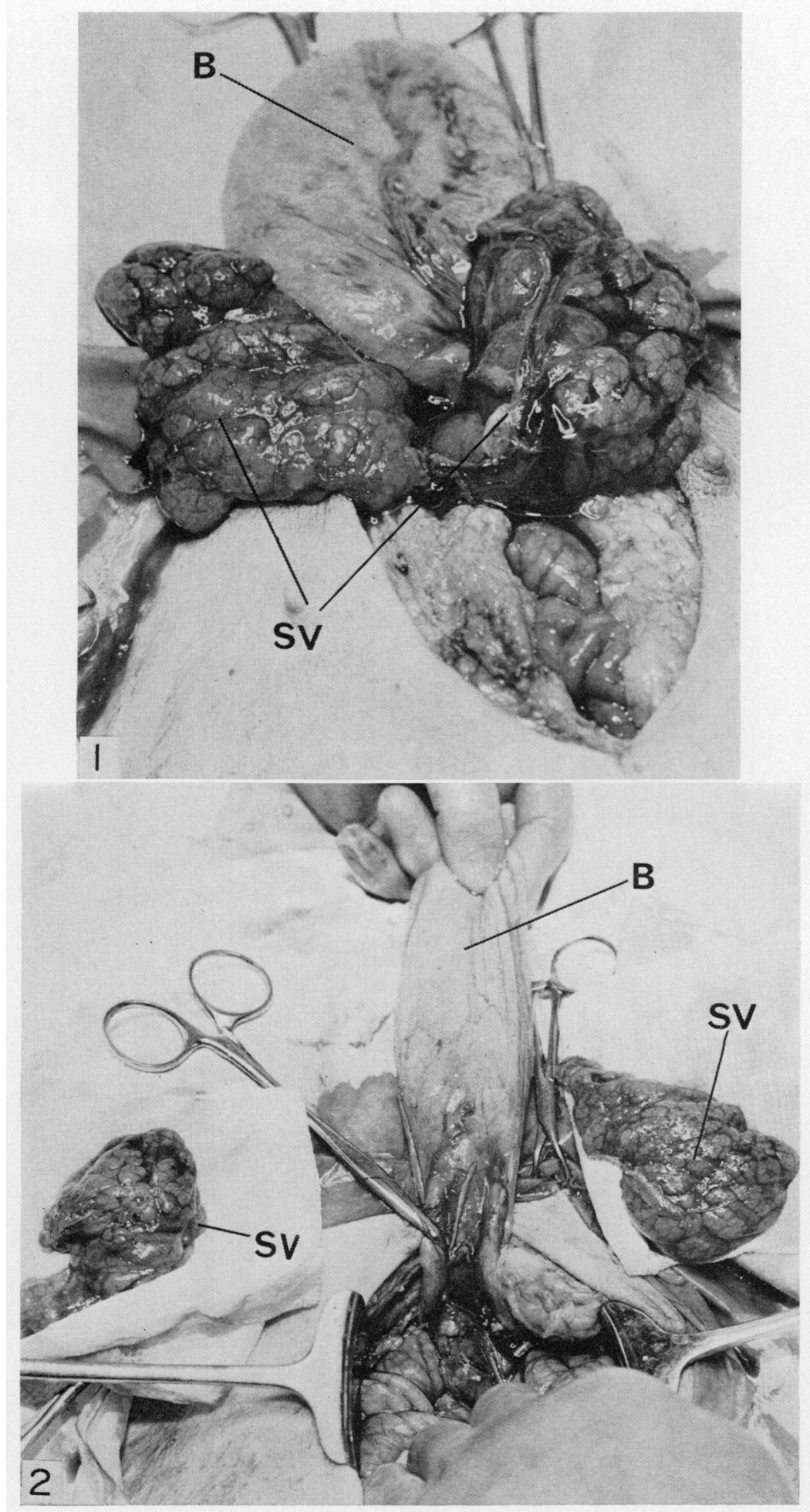


PLATE 2

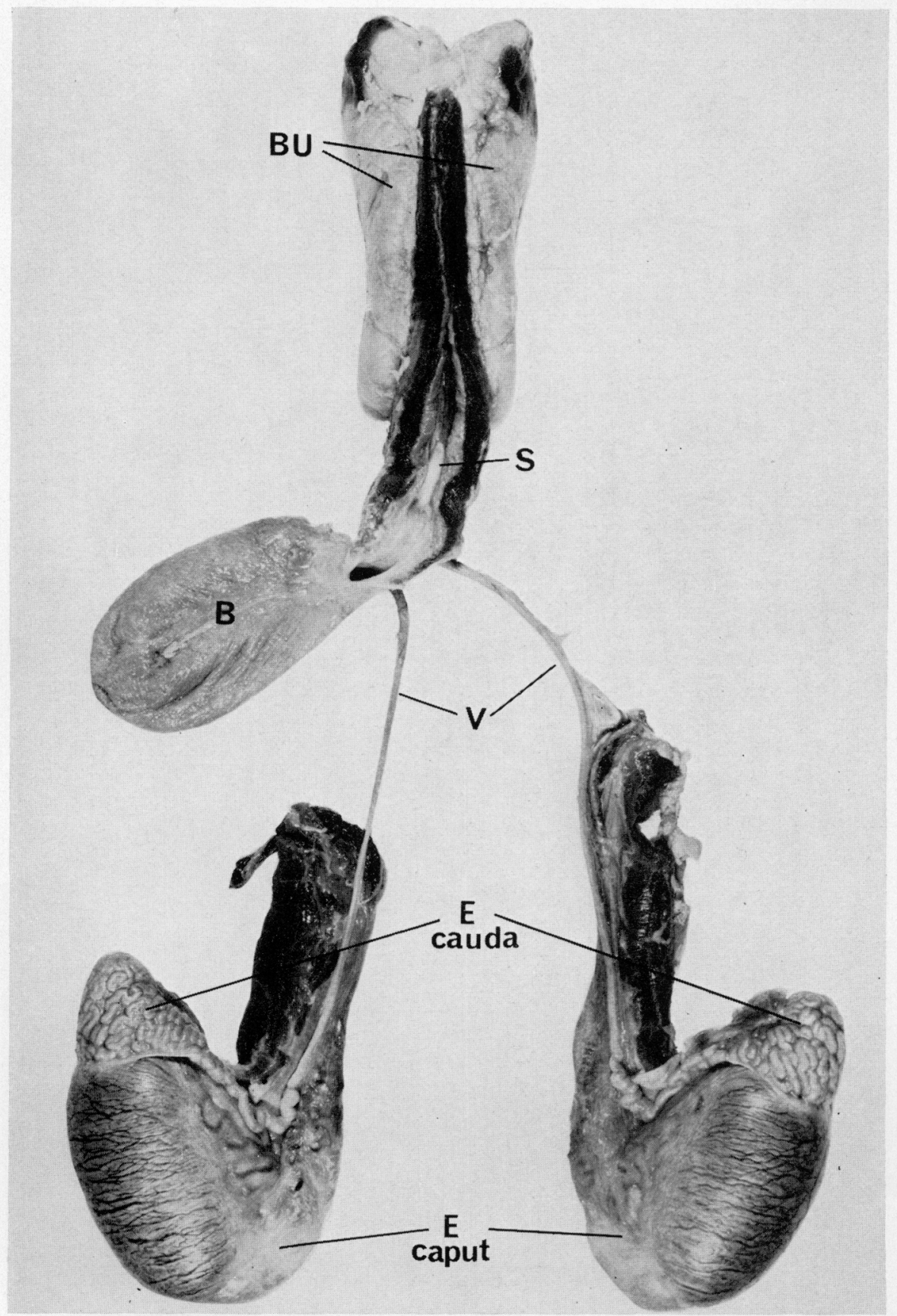

FIg. 3. Dissected genital tract from a boar 17 months after removal of the seminal vesicles. B, bladder; BU, bulbourethral gland; E, epididymis; S, semen; V, ductus deferens. 
Table 1. Progress of twelve boars following surgical removal of the seminal vesicles

\begin{tabular}{|c|c|c|c|c|}
\hline $\begin{array}{l}\text { Boar } \\
\text { no. }\end{array}$ & $\begin{array}{c}\text { Approx. age at } \\
\text { operation (months) }\end{array}$ & $\begin{array}{l}\text { Successful removal } \\
\text { of seminal vesicles }\end{array}$ & $\begin{array}{l}\text { Successfully trained } \\
\text { for semen collection }\end{array}$ & Remarks \\
\hline 1 & 6 & Yes & Yes & $\begin{array}{l}\text { Died at } 22 \text { months due to an anaes- } \\
\text { thesia accident }\end{array}$ \\
\hline 2 & 9 & Yes & No & $\begin{array}{l}\text { Slaughtered } 2 \text { months after surgery due } \\
\text { to an abscess in the tunica vaginalis }\end{array}$ \\
\hline $\begin{array}{l}3 \\
4 \\
5\end{array}$ & $\begin{array}{l}5 \\
4 \\
5\end{array}$ & $\begin{array}{l}\text { Yes } \\
\text { Yes } \\
\text { Yes }\end{array}$ & $\begin{array}{l}\text { Yes } \\
\text { Yes } \\
\text { No }\end{array}$ & \\
\hline 6 & 5 & No & No & $\begin{array}{l}\text { Right ductus deferens severed during } \\
\text { operation; animal slaughtered }\end{array}$ \\
\hline $\begin{array}{l}7 \\
8 \\
9\end{array}$ & $\begin{array}{l}5 \\
5 \\
5\end{array}$ & $\begin{array}{l}\text { Yes } \\
\text { Yes } \\
\text { Yes }\end{array}$ & $\begin{array}{l}\text { Yes } \\
\text { No } \\
\text { Yes }\end{array}$ & \\
\hline 10 & 5 & Yes & No & $\begin{array}{l}\text { Animal slaughtered due to a hypo- } \\
\text { plastic right testicle }\end{array}$ \\
\hline $\begin{array}{l}11 \\
12\end{array}$ & $\begin{array}{l}12 \\
12\end{array}$ & $\begin{array}{l}\text { Yes } \\
\text { Yes }\end{array}$ & $\begin{array}{l}\text { Yes } \\
\text { No }\end{array}$ & \\
\hline
\end{tabular}

The removal of the glands was shown to be completely successful in nine animals; six of these animals were trained for semen collection and produced semen with only small amounts of citrate and protein in the seminal plasma.

\section{Semen characteristics}

Samples of semen collected from the experimental boars and the control boars were studied at weekly intervals for the first 6 months after training. The seminal plasma from the boars after surgery had a more watery consistency and did not form the characteristic gel after ejaculation. A sticky secretion (probably of bulbourethral gland origin) was ejaculated which, when mixed with normal seminal plasma, absorbed fluid and gelled. The results of a number of observations made on the semen characteristics are presented in Table 2.

Table 2. A comparison of some characteristics of semen collected from intact boars and semen collected after removal of the seminal vesicles

\begin{tabular}{|c|c|c|c|}
\hline & Whole semen & $\begin{array}{l}\text { Semen after } \\
\text { removal of } \\
\text { seminal vesicles }\end{array}$ & Significance \\
\hline $\begin{array}{l}\text { Whole ejaculate volume (ml) } \\
\text { Whole ejaculate sperm concentration }\left(10^{8} \mathrm{ml}^{-1}\right) \\
\text { Seminal plasma protein (mg/ml) } \\
\text { Seminal plasma citrate concentration (mM) } \\
\text { Seminal plasma osmolarity (mosmol/kg) } \\
\text { Semen pH } \\
\text { 'Live/dead' stain (\% 'dead') }\end{array}$ & $\begin{array}{l}371 \pm 106(20) \\
3 \cdot 35 \pm 0 \cdot 92(20) \\
42 \cdot 1 \pm 3 \cdot 1(20) \\
7 \cdot 6 \pm 1 \cdot 7(20) \\
314 \pm 32(6) \\
7 \cdot 6 \pm 0 \cdot 14(15) \\
9-10(20)\end{array}$ & $\begin{array}{c}163 \pm 49(20) \\
1 \cdot 69 \pm 0 \cdot 34(20) \\
4 \cdot 3 \pm 1 \cdot 7(20) \\
0 \cdot 13 \pm 0.01(20) \\
318 \pm 26(6) \\
8 \cdot 21 \pm 0 \cdot 19(15) \\
9-10(20)\end{array}$ & $\begin{array}{l}P<0.05 \\
P<0.01 \\
P<0.01 \\
P<0.01 \\
\text { N.S. } \\
P<0.01 \\
\text { N.S. }\end{array}$ \\
\hline \multirow{2}{*}{$\begin{array}{l}\text { Fertility assessment } \\
\text { No. of gilts inseminated with two } 50-\mathrm{ml} \text { doses of } \\
2 \times 10^{7} \text { sperm. } \mathrm{ml}^{-1} \text { in IVT diluent }(18 \mathrm{hr} \text { apart)* } \\
\text { Conception rate }(\%) \\
\text { Average no. of fetuses }\end{array}$} & 17 & 17 & \\
\hline & $\begin{array}{c}60 \\
6 \cdot 7 \pm 2 \cdot 4\end{array}$ & $\begin{array}{r}41 \\
8 \cdot 0 \pm 3 \cdot 1\end{array}$ & $\begin{array}{l}\text { N.S. } \\
\text { N.S. }\end{array}$ \\
\hline
\end{tabular}

Values are expressed as means \pm S.D. The number of observations is shown in parentheses.

* For IVT diluent, see text. 
Sephadex G-200 gel filtration

The significant decrease in the concentration of the seminal plasma proteins described in Table 2 was confirmed in the Sephadex G-200 fractionation studies. Only trace amounts of the two principal peaks in the protein profile were present in samples from experimental animals (see Text-fig. 2); the shoulder on the second main peak of this sample appeared to be completely absent.

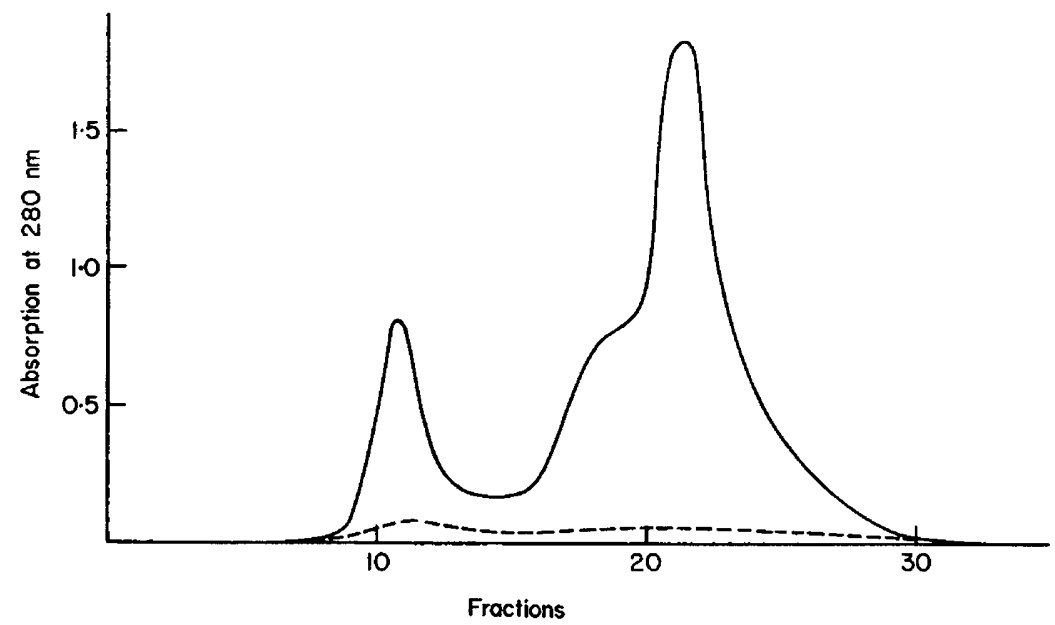

TexT-FIG. 2. Typical Sephadex G200 fractionation of the seminal plasma proteins from an intact boar $(\stackrel{)}{\longrightarrow}$ and one from which the seminal vesicles had been removed (- - - -).

\section{Fertility determination}

The conception rate following insemination of spermatozoa from experimental boars into seventeen gilts was compared with that for a similar group of gilts inseminated with the same number of viable spermatozoa from intact litter-mate boars (Table 2). Significant differences did not exist between the two groups of animals.

\section{Examination at autopsy}

An examination was made of the operation site and the reproductive tract of two boars slaughtered 17 months after surgery. In one animal, a plaque of calcified tissue approximately $5 \mathrm{~cm}$ long and $2.5 \mathrm{~cm}$ wide was observed in the tissues of the abdominal wall at the site of incision. Regeneration of the seminal vesicles had not occurred in either animal (PI. 2, Fig. 3) and adhesions between the organs were absent. The reproductive tract appeared normal, and the passage of spermatozoa from the epididymis to the penile urethra was not obstructed. This was shown by expressing sperm-rich fluid from the tail of the epididymis through the ductus deferens to the urethra.

\section{DISCUSSION}

The sperm concentration of the total ejaculate from boars after removal of the seminal vesicles was significantly lower $(49 \%)$ than the normal. As the semen 
volume was also reduced, the total spermatozoa for an ejaculate from boars without seminal vesicles was $78 \%$ lower than that from normal boars. No postoperative fever was observed that could have affected spermatogenesis and the testes from boars after surgery showed no deviation from the normal size. At autopsy, the genital tract was seen to be patent and without obstruction. Bower, Graham \& Crabo (1973) removed the seminal vesicles and bulbourethral glands from two miniature boars and showed that the sperm number was not affected. McKenzie et al. (1938), however, showed a substantial decrease in the number of ejaculated spermatozoa in a boar after the removal of the seminal vesicles. Alexander, Zemjanis, Graham \& Schmehl (1971) demonstrated a $38 \%$ decrease in the number of spermatozoa ejaculated by bulls after removal of their seminal vesicles.

Mann (1964) showed that citrate is secreted by the seminal vesicles. Only very low concentrations of citrate were detected in the seminal plasma of the experimental boars and these levels remained low, indicating that no regeneration had occurred. This absence of regeneration was also confirmed at autopsy.

The reason for the significantly higher $\mathrm{pH}$ values of the semen from the experimental boars is unclear since, in a series of titration experiments not reported in this paper, the semen from experimental and intact boars had the same buffering capacity to $0.1 \mathrm{~m}-\mathrm{NaOH}$ and $0.1 \mathrm{~m}-\mathrm{HCl}$. The $\mathrm{pH}$ of boar seminal plasma rapidly increases on standing due to loss of $\mathrm{CO}_{2}$, but in this study the $\mathrm{pH}$ measurements were made immediately after semen collections. McKenzie et al. (1938) found the $\mathrm{pH}$ of seminal vesicle secretion to be lower than that of whole semen and so removal of the seminal vesicles could conceivably increase seminal plasma $\mathrm{pH}$.

McKenzie et al. (1938) studied the performance of boars after the removal of the seminal vesicles, but the surgical technique was described only briefly. These surgical studies were carried out under sodium pentobarbitone anaesthesia and the glands were removed through a flank incision. In the present study, the glands were removed from an incision to one side of the prepuce and, although deep pelvic surgery was involved, no serious difficulties were encountered. The operation was a simple surgical procedure which required the minimum of equipment and manpower.

There were three failures in the series. The boar which was slaughtered due to the abscess in the tunica vaginalis obviously received the infection in the region of the colliculus seminalis during the surgical manipulation. The infection was not controlled by the administration of long-acting penicillin. Examination at autopsy revealed a thickened tunica vaginalis, but the testicular stroma was normal. The boar which was slaughtered owing to a hypoplastic right testicle was examined at autopsy but no disturbance to the blood supply of the testiscould be detected, and the testicular stroma appeared macroscopically normal.

The successful removal of the seminal vesicles from the boar has enabled these experimental animals to be used in the study of the storage of boar semen under deep-frozen conditions. These surgical preparations ensure a supply of semen containing only trace amounts of the basic proteins which may affect the integrity of the sperm membranes. 


\section{ACKNOWLEDGMENTS}

The authors gratefully acknowledge the assistance of Mrs J. L. Young for the citrate determinations and the financial support of the Meat and Livestock Commission to one of us (H.D.M.M.) for a studentship. Throughout the study, Mrs M. Hoare has given valuable surgical advice and surgical assistance has been provided by Miss J. Anderson and Miss S. MacCoskery. The authors acknowledge the help of $\mathrm{Mr}$ I. Jebbett who provided the photographs.

\section{REFERENCES}

Alexander, F. G. M., Zemjanis, R., Graham, E. F. \& Schmehl, M. L. (1971) Semen characteristics and chemistry from bulls before and after seminal vesiculectomy and after vasectomy. $\mathcal{F}$. Dairy Sci. 54, 1530-1535.

Boursneli, J. G. \& Briggs, P. A. (1969) Boar seminal plasma proteins. II. Electrophoretic identification of the haemagglutinin. 7. Reprod. Fert. 19, 157-166.

Boursnell, J. C., Johnson, P. \& Zamora, J. (1962) An electrophoretic and ultracentrifugal study of boar seminal plasma. Biochim. biophys. Acta, 63, 374-381.

Bower, R. E., JR, Graham, E. F. \& CRABo, B. (1973) A technique for collecting epididymal spermatozoa and fluids from the boar virtually free from accessory sex gland secretions. $\mathcal{J}$. Reprod. Fert. 33, 319-322.

DotT, H. M. \& Foster, G. C. (1972) A technique for studying the morphology of mammalian spermatozoa which are eosinophilic in a differential live/dead stain. 7 . Reprod. Fert. 27, 443-445.

Drew, M. \& McLaren, S. (1970) The effect of histones and other basic macromolecules on cell permeability and elongation of barley roots. Physiologia $P l .23,544-560$.

DU Mesnil du Bursson, F. \& Jondet, R. (1961) Utilization du $\mathrm{CO}_{2}$, dans l'insemination porcine. Proc. 4th Int. Congr. Anim. Reprod., The Hague, 4, 822-827.

Hancock, J. L. \& Hovel, G. L. C. (1959) The collection of boar semen. Vet. Rec. 71, $664-665$.

Hess, E. A., Ludwick, T. M., MartRig, R. C. \& Ely, F. (1960) Influence of seminal vesiculectomy on certain physical and biochemical properties of bovine semen. F. Dairy Sci. 43, 256-265.

Hibbitt, K. G. \& Benians, M. (1971) Some effects in vivo of the teat canal and effects in vitro of cationic proteins on Staphylococci. F. gen. Microbiol. 68, 123-128.

King, G. J. \& MacPherson, J. W. (1968) The effects of seminal vesiculectomy on the fertility of frozen bovine semen. Proc. 6th Int. Congr. Anim. Reprod. $\mathcal{E}$ A.I., Paris, 2, 1259-1261.

LAYne, E. (1957) Protein estimation by ultraviolet absorption. In Methods in Enzymology, Vol. 3, pp. 451-454. Eds. S. P. Colowick and N. O. Kaplan. Academic Press, New York.

Lowry, O. H., Rosebrough, N.J., FARR, A. L. \& Randall, R. J. (1951) Protein measurement with the Folin phenol reagent. 7. biol. Chem. 193, 265-275.

McKenzie, F. F., Muller, J. C. \& Bauguess, L. C. (1938) The reproductive organs and semen of the boar. Bull. Univ. Mo. Agric. Exp. Stn, No. 279.

Mann, T. (1964) The Biochemistry of Semen and of the Male Reproductive Tract. John Wiley, New York.

Molifering, H. \& Gruber, W. (1966) Determination of citrate with citrate lyase. Analyt. Biochem. 17, 369-379.

Ryser, H. J.-P. \& HANCock, R. (1965) Histones and basic polyamino acids stimulate the uptake of albumin by tumour cells in culture. Science, $\mathcal{N} . Y .150,501-503$.

Schellpfeffer, D. A. \& Hunter, A. G. (1970) Behaviour of boar seminal plasma proteins before and after removal of accessory sex glands. 7 . Reprod. Fert. 23, 291-298.

Shaf, B. A., Hopwood, M. L. \& Faulkner, L. C. (1968) Seminal vesiculectomy in bulls. I. Seminal biochemistry. 7. Reprod. Fert. 16, 171-177. 